\title{
AGROINDUSTRIAL WASTE APPLICATION FOR DRUGS BIOSORPTION ${ }^{1}$ APLICAÇÃO DE RESÍDUOS AGROINDUSTRIAIS PARA A BIOSSORÇÃO DE FÁRMACOS
}

\author{
Matheus Londero da Costa ${ }^{2}$, João Pedro Martins Resmini ${ }^{2}$, \\ Noeli Júlia Schüssler de Vasconcellos ${ }^{3}$ and William Leonardo da Silva ${ }^{44}$
}

\begin{abstract}
Currently, one of the main focuses globally is the stability of the environment for future generations. For this to be possible, it is necessary to preserve natural resources, such as water, as it is essential for the continuity of life on the planet. However, due to the massive increase in residual water and the improper consumption of medications, which are generally not fully metabolized, being excreted inappropriately, becoming an environmental liability. In this context, several treatment techniques have been used to promote the correct disposition for this wastewater, highlighting the adsorption process due to its ease, low cost, and the possibility of using alternative materials (biosorbents). Thus, the present work aims to present a bibliographic review of a qualitative and exploratory character on the application of agro-industrial residues, as alternative materials, for the removal of medicines, through a study of adsorption equilibrium, using the Langmuir, Freundlich, Temkin and Sips isotherms and adsorption kinetics, using the Pseudo-First-Order, Pseudo-Second-Order and Elovich models. Therefore, research demonstrated positive results in the removal of organic pollutants such as the industrial use of cork and peach kernel for the removal of paracetamol, where a $Q_{\text {máx }}$ of 200 and $113 \mathrm{mg} \mathrm{g}^{-1}$ was obtained for Langmuir, n of 3.1 and 2.4 for Freundlich agreeing with the same, and having an optimal Pseudo-SecondOrder kinetics of $\mathrm{R}^{2}$ of 0.999 for both, therefore, with this article it was possible to verify the use of several biosorbent in the removal of the mentioned drugs previously.
\end{abstract}

Keywords: Adsorption; Ibuprofen; Paracetamol; Kinetics; Isotherms.

\section{RESUMO}

Atualmente, um dos principais focos globalmente é a estabilidade do meio ambiente para as gerações futuras. Para que isso seja possivel, é preciso preservar os recursos naturais, como a água, que é essencial para a continuidade da vida no planeta. Porém, devido ao aumento maciço da água residual e ao consumo inadequado de medicamentos, que geralmente não são totalmente metabolizados, sendo excretados de forma inadequada, tornando-se um passivo ambiental. Nesse contexto, diversas técnicas de tratamento têm sido utilizadas para promover o correto descarte dessa água residuária, destacando-se o processo de adsorção pela facilidade, baixo custo e possibilidade de utilização de materiais alternativos (biossorventes). Assim, o presente trabalho tem como objetivo apresentar uma revisão bibliográfica de caráter qualitativo e exploratório sobre a aplicação de resíduos agroindustriais, como materiais alternativos, para a remoção de medicamentos, por meio de um estudo de equilibrio de adsorção, utilizando os modelos de equilibrio de Langmuir, Freundlich, Temkin e Sips e cinética de adsorção, utilizando os modelos Pseudo-Primeira-Ordem, Pseudo-Segunda-Ordem e Elovich. Portanto, pesquisas demonstraram resultados positivos na remoção de poluentes orgânicos como o uso

1 Scientific Initiation, Franciscan University, Santa Maria, RS, Brazil.

2 Chemical Engineering Course, Franciscan University, Santa Maria, RS, Brazil. E-mail: matheus.londero@ufn.edu.br; j.resmini@ufn.edu.br

3 Environmental and Sanitary Engineering Course, Franciscan University, Santa Maria, RS, Brazil. E-mail: julia@ufn.edu.br 4 Nanoscience Graduate Program, Franciscan University, Santa Maria, RS, Brazil. E-mail: w.silva@ufn.edu.br 
industrial de cortiça e caroço de pêssego para remoção de paracetamol, onde foi obtido um $Q_{\text {máx }}$ de 200 e 113 mg $g^{-1}$ para Langmuir, $n$ de 3,1 e 2,4 para Freundlich estando de acordo com o mesmo, e tendo uma cinética de Pseudo-Segunda-Ordem ótima de $R^{2}$ de 0,999 para ambos, portanto, com este artigo foi possível verificar o uso de diversos biossorventes na remoção dos fármacos citados anteriormente.

Palavras-chave: Adsorção; Ibuprofeno; Paracetamol; Cinética; Isotermas.

\section{INTRODUTION}

The permanence time of environmental stability and its hydric resources is extremely necessary to the continuity of life on our planet. Environmental preservation is being supported by our attitudes on how not to waste environmental resources and the compliance of human actions to reduce the pollutants made on methods of production (SANTA et al., 2021) The performance of industry it's the author of the huge scale of toxic waste to the human wealth, fauna, and flora. In general, this sludge is fluids that must be handled previously which depends a lot on which chemical compounds are found in it before being released on natural sources like water (PRIYA et al., 2021).

Moreover, agro-industrial waste usually is solid and on average, where the incorrect destination of this debris can become a possible harmful substance to the environment (MARTINEZBURGOS et al., 2021). Brazil is the third largest worldwide producer of fruits with around 45 million tons a year, indicating around $65 \%$ are internally consumed and 35\% are intended for the external market (DA SILVA; CASTAÑEDA-AYARZA, 2021). For instance, many works have been carried out to promote a new destiny to this waste, such as reusing and transforming it into new technology.

In parallel, Brazil has a serious problem with self-medication, mainly analgesics (paracetamol, ibuprofen, and sodium diclofenac), because of ease of acquisition without medical prescription for the population (GAMA; SECOLI, 2020). Moreover, these drugs end up not being fully absorbed by the human body being so end up discharged in hydro bodies without appropriate treatment (RATHI; KUMAR; SHOW, 2021). Among techniques of water treatment, the adsorption process comes as an alternative, because there are some advantages such as easy operation, low cost, and the possibility to use of adsorbent, for example, agro-industrial waste (BOTELLO-GONZÁLEZ; DÁVILAGUZMÁN; SALAZAR-RÁBAGO, 2021). Thus, the adsorption process has been used effectively on organic pollutant removal, with the utilization of alternative material (waste) (THUE et al., 2018; DA SILVA; DOS SANTOS, 2017). Being so, some agro-industrial waste has been used such as biosorbent, for example, olive biomass (RODRIGUES et al., 2020), sugar cane biomass (KARRI; SAHU; MEIKAP, 2020), rice husk (ALVER; METIN; BROUERS, 2020), grape biomass (SHAHRAKI; SHARIFIFARD; LASHANIZADEGAN, 2018), banana husk (OLUWATOYIN; OLALEKAN, 2021), soya husk (BANU; KARTHIKEYAN; MEENAKSHI, 2019), corncob (SUN et al., 2021), wheat straw 
(CAO et al., 2019), coffee husk (TRAN et al., 2020) and orange biomass (KADAM et al., 2020), to the removal of pollutants on wastewater, in majority organic pollutants such as drugs, dyes and pesticides.

Therefore, this work aims to present a critical analysis of studies using agro-industrial residues in the drug adsorption process, evaluating the parameters of equilibrium models and adsorption kinetics.

\section{MATERIALS AND METHODS}

The present work consists of an exploratory and qualitative bibliographic review that encompasses the use of agro-industrial waste to remove drugs in the process of adsorption. Thus, it was realized researches using the Science Direct platform (www.sciencedirect.com), with keywords "adsorption"; with "drugs" (paracetamol; sodium diclofenac and ibuprofen), during the period of 2018-2021, where were found around 6,237 articles, according to Figure 1.

Figure 1 - Bibliographic research about drugs adsorption during the period of 2018- 2021.

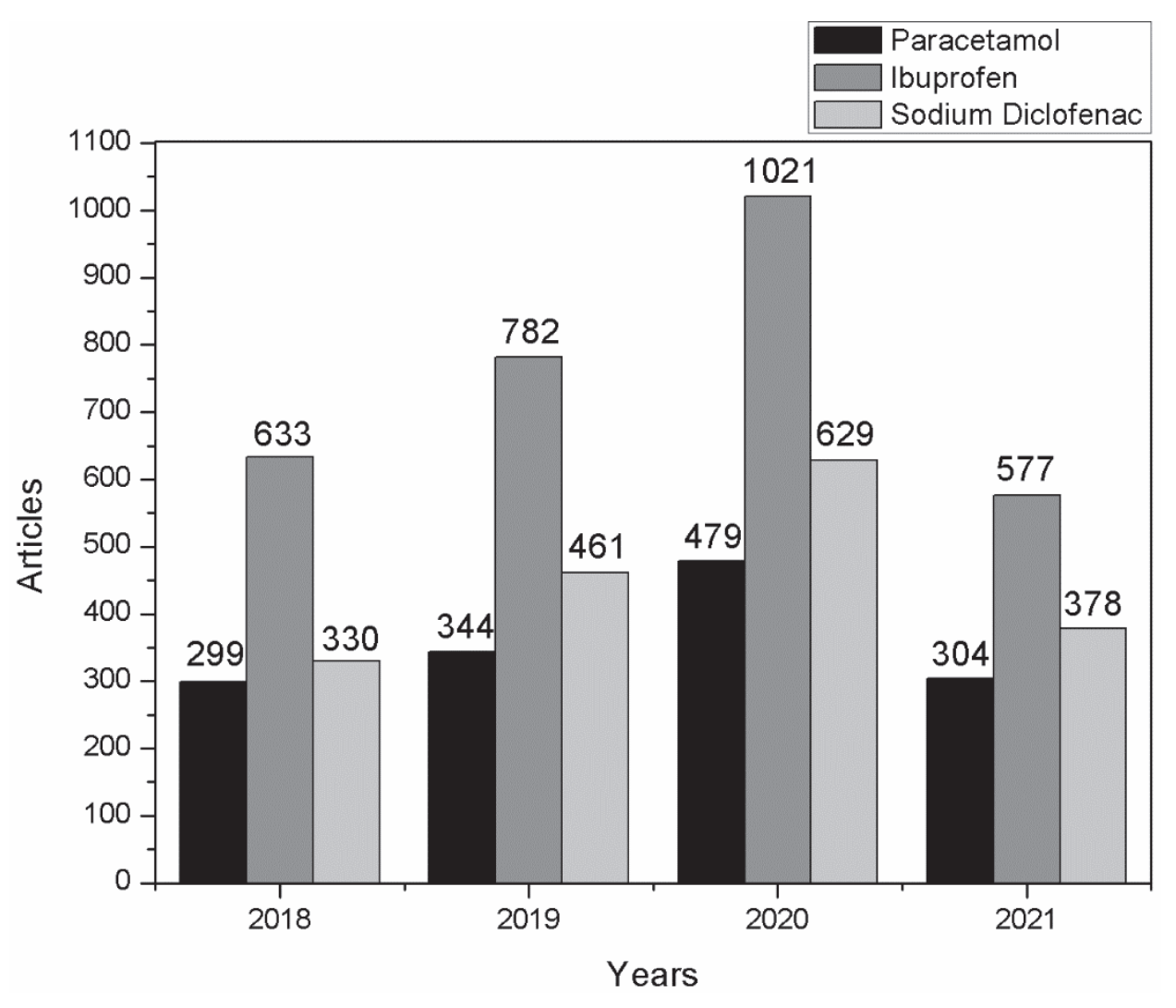

Source: Author's Construction

According to the Figure 1, it was possible observed that there are many studies related to the adsorption process and drugs, mainly with ibuprofen. Moreover, a significant increase in publications, highlighting $60.20,61.30$ and $90.60 \%$ to studies with paracetamol, ibuprofen and sodium diclofenac, respectively. 
PARACETAMOL

The paracetamol (acetaminophen) is an analgesic and antipyretic, derived by $\rho$-aminophenol, where were introduced such as a substitute for acetanilide. Moreover, when this is managed, the drug comes across to the liver and becomes $p$-aminophenol that will be metabolized on the brain and sent to the renal, where will be the way to distribute to the rest of the body such as an analgesic effect. After being absorbed by the organism, around $90 \%$ of the medicine can be recovered in the urine on the first day of use (DUBRAY; MAINCENT; MILON, 2021).

In parallel, paracetamol research indicates there are small detectable amounts in sewage treatment plants (STPs) on the range of $\mu \mathrm{g} \mathrm{L}^{-1}$ until mg L ${ }^{-1}$, which becomes relevant for the process of decontamination for being defined like an emerging micropollutant (MOJIRI et al., 2020). Figure 2 shows the chemical molecular structure of paracetamol, and Table 2 exposed the main properties of itself.

Figure 2 - Chemical structure of paracetamol drug.

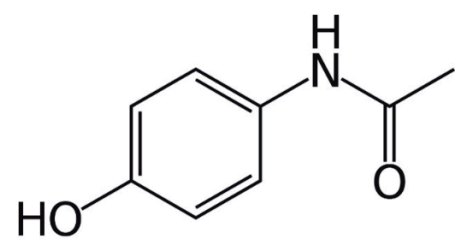

Source: Author's Construction

Table 2 - Main properties of paracetamol drug.

\begin{tabular}{cccc}
\hline molecular formula & weight molecular $\left(\mathbf{g ~ m o l}^{-1}\right)$ & solubility $\left(\mathbf{m g ~ l} \mathbf{~ l}^{-1}\right)$ & $\boldsymbol{\lambda}_{\max }(\mathbf{n m})$ \\
\hline $\mathrm{C}_{8} \mathrm{H}_{9} \mathrm{NO}_{2}$ & 151.16 & 14 & 257 \\
\hline \multicolumn{4}{c}{}
\end{tabular}

\section{SODIUM DICLOFENAC}

Sodium Diclofenac is one of the AINES (anti-inflammatory nonsteroidal) more used analgesics medicines, anti-inflammatory e anti-febrile (SAAD et al., 2021). For is one effective inhibitor of the oxygenasis cycle, where it is used to relieve pain and inflammatory diseases, especially rheumatoid arthritis, osteoarthritis, bursitis, tendonitis, surgical pain and spondylitis (ATZENI; MASALA; PUTTINI, 2018) However, there are studies showing the presence of sodium diclofenac on the aquatic environment, since this is consumed in large quantities with a low rate of removal by conventional treatments used in sewage treatment plants (SHAKEEL et al., 2014; QUESADA et al., 2019). It does not have adverse effects in therapeutics dosages, however, when overloaded, it can form ulcers, bleeding and hepatic disease (STÜLTEN, 2008). With a large amount of the drug in the environment, occasionally may occur intoxication, which can lead to health problems as vomit, gastrointestinal hemorrhage, 
diarrhea, dizziness, tinnitus, or convulsions. In the case of severe intoxication, acute kidney and liver insufficiency may occur. Figure 3 shows the chemical structure of sodium diclofenac, and Table 3 exposed the main properties of itself.

Figure 3 - Chemical structure of sodium diclofenac drug.<smiles>O=C(Cc1ccccc1Nc1c(Cl)cccc1Cl)O[Na]</smiles>

Source: Author's Construction.

Table 3 - Main properties of sodium diclofenac.

\begin{tabular}{cccc}
\hline molecular formula & weight molecular $\left(\mathbf{g ~ m o l}^{-1}\right)$ & solubility $\left(\mathbf{m g ~ l}^{-1}\right)$ & $\boldsymbol{\lambda}_{\text {max }}(\mathbf{n m})$ \\
\hline $\mathrm{C}_{14} \mathrm{H}_{11} \mathrm{Cl}_{2} \mathrm{NO}_{2} \mathrm{Na}$ & 296.20 & 2.37 & 275 \\
\hline \multicolumn{4}{c}{ Source: Sotelo et al. $(2014)}$.
\end{tabular}

\section{IBUPROFEN}

Ibuprofen is an anti-inflammatory nonsteroidal and has analgesic and antipyretic effects (PAROLINI, 2020), showing the combination with two active principles used to relieve rheumatic pain (ATZENI et al., 2021). Moreover, it is easy to get without a medical prescription and is not on the list of pharmaceutical assistance (RENAME) (BEHERA; OH; PARK, 2012). Moreover, the abundance of this drug in the environment leads to intoxication that causes health problems such as anemia, hypersensitivity, dermatology problems such as photosensitivity and ocular effects as blurry diplopia (HUSSAIN et al., 2021) Figure 4 shows the chemical structure of ibuprofen and the Table 4 exposed the main properties of itself.

Figure 4 - Chemical structure of ibuprofen drug.<smiles>CC(C)Cc1ccc(C(C)C(=O)O)cc1</smiles>

Source: Author's Construction.

Table 4 - Main properties of ibuprofen drug.

\begin{tabular}{cccc}
\hline molecular formula & weight molecular $\left(\mathbf{g ~ m o l}^{-\mathbf{1}}\right)$ & solubility $\left(\mathbf{m g ~ \mathbf { l } ^ { - 1 }}\right)$ & $\boldsymbol{\lambda}_{\max }(\mathbf{n m})$ \\
\hline $\mathrm{C}_{13} \mathrm{H}_{18} \mathrm{O}_{2}$ & 206.29 & 21 & 220 \\
\hline \multicolumn{4}{c}{}
\end{tabular}




\section{BIOSORPTION PROCESS}

Normally the use of biosorbents requires the preparation of the same (biochar), with this biochar the biosorption process normally lasts between 120 to 180 minutes, where samples are collected at predetermined times, right after using a photometer spectrum to observe the absorbance at each collected point, therefore, isotherms are used for the study of adsorption and kinetic models to verify how fast the adsorption process happens (HUSSAIN et al., 2021).

\section{Biosorption equilibrium}

In the study of the adsorption equilibrium, Langmuir, Freundlich, Sips and Temkin isotherms are used most, which require $\mathrm{Ce}$ which is the concentration of the adsorbent in the liquid phase equilibrium adsorbed, thus it is possible to identify the characteristics of the adsorption process as shown in Table 5. Thus, Table 5 shows the bibliographic study about the main methods to identify the adsorption equilibrium process in relation to the isotherm's models.

Table 5 - Isothermal models and their equations with descriptions of their variables.

\begin{tabular}{|c|c|c|c|}
\hline Model & Equation & Comments & Reference \\
\hline Langmuir & $q_{e}=\frac{q_{m a ́ x} * C_{e}}{1+k_{L} * C_{e}}$ & $\begin{array}{l}\text { Langmuir's isotherm defends the idea that the biosorbents have an active site } \\
\text { for each molecule of the adsorbate, so an adsorption occurs in a monolayer. }\end{array}$ & $\begin{array}{l}\text { LANGMUIR } \\
\qquad(1918)\end{array}$ \\
\hline Freundlich & $q_{e}=k_{F} * C_{e}^{\frac{1}{n_{F}}}$ & $\begin{array}{l}\text { The Freundlich isotherm, on the other hand, defends the idea that the biosor- } \\
\text { bent has an active site for more than one molecule of the adsorbate, there- } \\
\text { fore the adsorption occurs in a multilayered form. }\end{array}$ & $\begin{array}{l}\text { FREUNDLICH } \\
\text { (1926) }\end{array}$ \\
\hline Sips & $q_{e}=\frac{q_{m a ́ x} *\left(k_{S} * C_{e}\right)^{n_{S}}}{1+\left(k_{S} * C_{e}\right)^{n}}$ & $\begin{array}{l}\text { The Sips isotherm consists of the union of the Langmuir and Freundlich } \\
\text { isotherms, therefore if the value of } n_{\mathrm{s}} \text { is equal to } 1 \text { it is equal to Langmuir }\end{array}$ & SIPS (1948) \\
\hline Temkin & $q_{e}=\frac{R T}{b} * \ln \left(k_{T} * C_{e}\right)$ & $\begin{array}{l}\text { The Temkin isotherm is normally used in the adsorption of gases, which de- } \\
\text { fines whether the adsorption occurs physically }\left(<20 \mathrm{~kJ} \mathrm{~mol}^{-1}\right) \text { or chemical } \\
\left(\geq 20 \mathrm{~kJ} \mathrm{~mol}^{-1}\right)\end{array}$ & $\begin{array}{c}\text { TEMKIN } \\
(1941)\end{array}$ \\
\hline
\end{tabular}

Where:

$\mathrm{q}_{\mathrm{e}}$ : quantity of molecule adsorbed in equilibrium with solution per unit mass ( $\mathrm{mg}$ of adsorbate $\mathrm{g}$ of adsorbent $^{-1}$ );

$\mathrm{q}_{\text {máx }}$ : maximum amount of molecule adsorbed in solution per unit of mass to form a complete monolayer of adsorption

( $\mathrm{g}$ of adsorbate $\mathrm{g}$ of adsorbent $\mathrm{t}^{-1}$ );

$\mathrm{k}_{\mathrm{L}}$ : Langmuir constant $\left(\mathrm{L} \mathrm{mg}^{-1}\right)$;

Ce: concentration of the adsorbent in the liquid phase equilibrium adsorbed $\left(\mathrm{g} \mathrm{L}^{-1}\right)$;

$\mathrm{k}_{\mathrm{F}}$ : Freundlich constant;

$\mathrm{n}_{\mathrm{F}}$ : represents the degree of heterogeneity of the system, ranging from 1 to 10 ;

$\mathrm{k}_{\mathrm{S}}$ : Sips isotherm constant, with the adsorption energy $\left(\mathrm{L} \mathrm{mg}^{-1}\right)$;

$\mathrm{n}_{\mathrm{S}}$ represents the degree of heterogeneity of the system, ranging from 0 to 1 ;

$\mathrm{k}_{\mathrm{T}}$ : is the bonding equilibrium constant $\left(\mathrm{L} \mathrm{mg}^{-1}\right)$;

$\mathrm{b}$ : is the heat of adsorption ( $\mathrm{kJ}$ mol-1);

$\mathrm{R}$ : is the universal gas constant $\left(8,314 \mathrm{~J} \mathrm{~K}^{-1} \mathrm{~mol}^{-1}\right)$;

$\mathrm{T}$ : is the temperature $(\mathrm{K})$. 
Moreover, Figure 5 shows us the behavior of isotherms in a generic way, making it possible to graphically identify when the adsorption becomes favorable or unfavorable.

Figure 5 - Adsorption isotherms correlating equilibrium concentration $\left(\mathrm{mg} \mathrm{L}^{-1}\right)$ and adsorbed capacity $\left(\mathrm{mg} \mathrm{g}^{-1}\right)$.

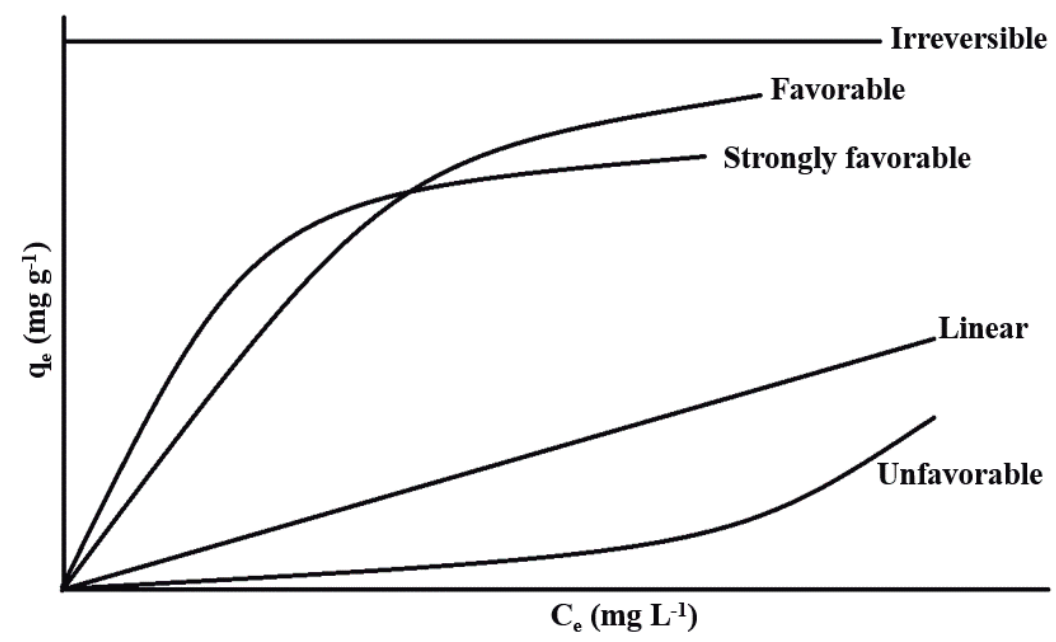

Source: Author's Construction.

\section{Biossorption kinetic}

The kinetic models describe how fast the reaction occurs, among the most common models are pseudo-first-order (PFO), pseudo-second-order (PSO) and Elovich (ELO), when PFO is more favorable, this means that there is an excess of reagent (FARID et al., 2018), on the other hand for PSO the adsorption rate depends on the amount of the chemical species adsorbed on the surface of the adsorbent and the amount adsorbed at steady state (HUBBE; AZIZIAN, DOUVEN, 2019) while for the ELO with the increase of the mass of the smaller adsorbate will be its constant ( $\omega$ ) (BERNAL; GIRALNDO; MORENO-PIRAJÁN,2021).

\section{BIOCHAR}

Biochar is an activated carbon from biomass residual, which shows high porosity and surface area, with properties attributed to its surface, including the removal of impurities dissolved in solution (RAVENNI et al., 2020). Moreover, it is synthesized by the activation/carbonization process. However, this thermic decomposition has the following limitations, such as (HUANG et al., 2020): (a) oxygen concentration: environment; (b) temperature rate: $500{ }^{\circ} \mathrm{C}$ and, (c) time of pyrolysis:5 hours. 


\section{RESULTS AND DISCUSSION}

\section{BIOSSORPTION EQUILIBRIUM}

Table 6 and Table 7 show some studies using different biosorbents to organic pollutants removal through the adsorption equilibrium using different isotherm models, such as Langmuir and Freundlich (Table 6) and Temkin and Sips (Table 7).

Table 6 - Equilibrium adsorption to drug removal using Langmuir and Freundlich isotherms.

\begin{tabular}{|c|c|c|c|c|c|c|c|c|c|}
\hline \multirow[b]{2}{*}{ Drug } & \multirow[b]{2}{*}{$\begin{array}{l}\text { Biosorvent } \\
\quad\left(\mathrm{g} \mathrm{L}^{-1}\right)\end{array}$} & \multirow[b]{2}{*}{$\begin{array}{c}\text { Drug } \\
\left(\mathrm{mg} \mathrm{l}^{-1}\right)\end{array}$} & \multirow[b]{2}{*}{$\mathbf{T}\left({ }^{\circ} \mathbf{C}\right)$} & \multirow[b]{2}{*}{ pH } & \multicolumn{2}{|c|}{ Langmuir } & \multicolumn{2}{|r|}{ Freundlich } & \multirow[t]{2}{*}{ Reference } \\
\hline & & & & & $\begin{array}{c}Q_{\text {máx }} \\
\left(\mathrm{mg} \mathrm{g}^{-1}\right)\end{array}$ & $\begin{array}{c}\mathrm{K}_{\mathrm{L}} \\
\left(\mathrm{L} \mathrm{mg}^{-1}\right)\end{array}$ & $\mathbf{n}$ & $\begin{array}{c}\mathbf{K}_{\mathrm{F}} \\
\left(\mathbf{L}^{1 / n} \cdot \mathbf{m g}^{1-1 / n} \cdot \mathbf{g}^{-1}\right)\end{array}$ & \\
\hline Ibuprofen & $\mathrm{CM}(0.2)$ & 1 & $25-40$ & $4-6$ & 0.4 & 0.002 & 1.9 & 5.5 & $\begin{array}{c}\text { ŻÓŁTOWSKA- } \\
\text { AKSAMITOWSKA et al. (2018) }\end{array}$ \\
\hline Ibuprofen & $\begin{array}{l}\text { WASAB } \\
(0.03-0.45)\end{array}$ & $20-45$ & $15-45$ & $2-6$ & 12.7 & 0.08 & 0.6 & 1.3 & CHAKRABORTY et al. (2018) \\
\hline Paracetamol & $\mathrm{IC}(0.1)$ & 120 & 30 & 7.5 & 200 & 0.4 & 3.1 & 55.7 & CABRITA et al. (2010) \\
\hline Paracetamol & PS $(0.1)$ & 120 & 30 & 9.0 & 113 & 0.05 & 2.4 & 15.4 & CABRITA et al. (2010) \\
\hline $\begin{array}{c}\text { Sodium } \\
\text { Diclofenac }\end{array}$ & $\operatorname{COC}(0.2)$ & $0.15-0.30$ & $15-50$ & 7.0 & 0.1 & 185.9 & 0.2 & 0.1 & MAIA et al. (2019) \\
\hline $\begin{array}{c}\text { Sodium } \\
\text { Diclofenac }\end{array}$ & $\operatorname{PCSP}(0.2)$ & 100 & 34.9 & 6.6 & 493.8 & 0.006 & 0.6 & 11.8 & LU et al. (2020) \\
\hline
\end{tabular}

CM - modified chitin; WASAB - apple tree wood biochar activated with steam;

IC - industrial cork; PS - peach kernel; commercial organoclay;

CMW - modified chitosan residue, COC - commercial organoclay, PCSP - poly (vinyl alcohol)/chitosan/amino-grafted silica@polyethylenimine, $\mathrm{Q}_{\text {máx }}$ - Maximum adsorption; $\mathrm{K}_{\mathrm{L}}$ - Langmuir constant, $\mathrm{K}_{\mathrm{F}}$ - For the Freundlich.

According to Table 6, for the ibuprofen drug, $\mathrm{Q}_{\text {máx }}$ ranged 0.40 - $12.66 \mathrm{mg} \mathrm{g}^{-1}$ using $\mathrm{CM}$ and WASAB, respectively, that is, going to meet Langmuir and for Freundlich the only was from CM, since the value of $n$ must be between 1 and 10. For paracetamol, both biosorbents IC and PS were favorable for both Langmuir and Freundlich, and for sodium diclofenac only PCSP was favorable for Langmuir and none for Freundlich.

Table 7 - Relation of the drugs using Temkin and Sips isotherms.

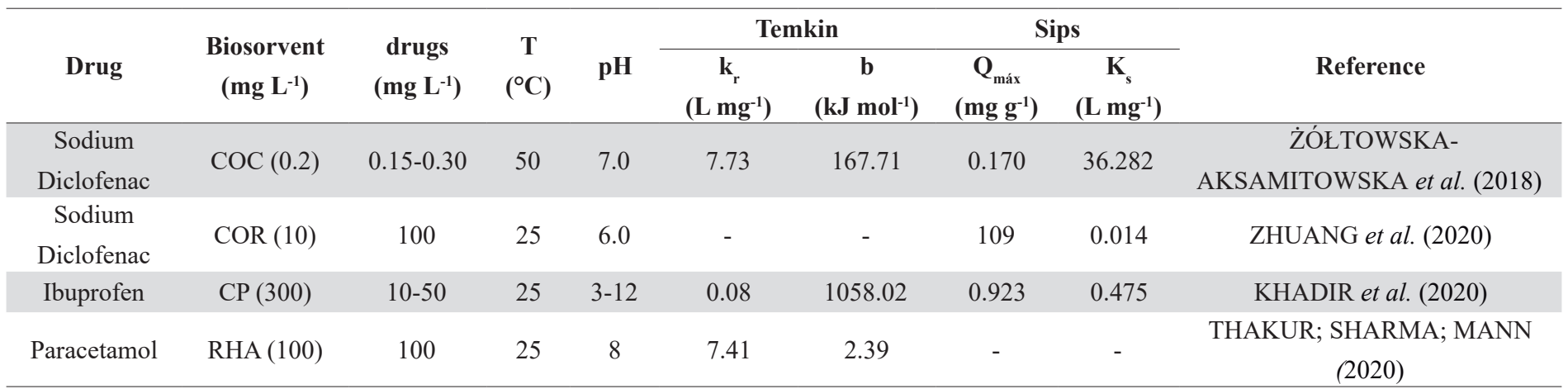


In Table 7, it is possible to observe that RHA was the only one that obtained physical adsorption according to Temkin due to the low energy adsorption $\left(<20 \mathrm{~kJ} \mathrm{~mol}^{-1}\right)$, and for Sips, the COC was the one with the highest maximum capacity $\left(\mathrm{Q}_{\text {max }}\right)$, furthermore, research has shown the lack of research of these isotherms with the above drugs, due to the Temkin isotherm being generally used for gases.

\section{ADSORPTION KINETICS}

The kinetic study will be essential to determine the speed at the adsorption process occurs, being possible to verify the mechanism and the main kinetic parameters. Thus, pseudo-first order (PFO), pseudo-second order (PSO) and Elovich (ELO) models are mainly models used in kinetic adsorption studies. Table 8 shows the main kinetic parameters used in the study of some drugs, such as ibuprofen, paracetamol and sodium diclofenac.

Table 8 - Kinetic studies conducted with drugs (ibuprofen, paracetamol and sodium diclofenac).

\begin{tabular}{|c|c|c|c|}
\hline Drugs & $\begin{array}{l}\text { Kinetic } \\
\text { model }\end{array}$ & Comments & Reference \\
\hline Ibuprofen & $\begin{array}{l}\text { PFO and } \\
\text { PSO }\end{array}$ & $\begin{array}{l}\text { Study in relation to ibuprofen removal where was used WASAB for } \\
\left.\text { adsorption the same ( } 15 \text { and } 30 \mathrm{mg} \mathrm{L}^{-1}\right) \text {, where was obtained } \mathrm{R}^{2} \text { the } \\
\text { PFO } 0.859 \text { and PSO } 0.900 \text {. }\end{array}$ & $\begin{array}{l}\text { CHAKRABORTY } \\
\text { et al. (2018) }\end{array}$ \\
\hline $\begin{array}{l}\text { Ibuprofen } \\
\text { and Sodium } \\
\text { Diclofenac }\end{array}$ & $\begin{array}{l}\text { PFO and } \\
\text { PSO }\end{array}$ & $\begin{array}{l}\text { This study relation shows the utilization the CM to removal } \\
\text { ibuprofen and sodium diclofenac, using PFO and PSO kinetics for } \\
\text { evaluation, where was obtained to PFO a R } \mathrm{R}^{2} \text { the } 0.138 \text { and } 0.124 \text { and } \\
\text { PSO } \mathrm{R}^{2} \text { the } 0.999 \text { for both }\end{array}$ & $\begin{array}{l}\text { PHASUPHA; } \\
\text { PRAPHAIRAKSIT; } \\
\text { IMYIM (2019) }\end{array}$ \\
\hline Paracetamol & PSO & $\begin{array}{l}\text { Study in relation to paracetamol removal where was used IC and } \\
\text { PS for adsorption the same }\left(120 \mathrm{mg} \mathrm{L}^{-1}\right) \text {, the } \mathrm{R}^{2} \text { for PSO obtained } \\
\text { was the } 0.999\end{array}$ & CABRITA et al. (2010) \\
\hline Ibuprofen & $\begin{array}{l}\text { PFO, PSO } \\
\text { an ELO }\end{array}$ & $\begin{array}{l}\text { Study in relation to ibuprofen removal where was used coconut husk } \\
\text { activated (ACH) for the same, using PFO, PSO and ELO kinetics, } \\
\text { where was obtained to PFO a } \mathrm{R}^{2} \text { the } 0.937 \text {, for PSO a } \mathrm{R}^{2} 0.993 \text { and } \\
\text { for ELO a R } \mathrm{R}^{2} \text { the } 0.865\end{array}$ & BELLO et al. (2020) \\
\hline
\end{tabular}

We can see in table 7 that the kinetics was not favored by CM, due to its $\mathrm{R}^{2}$ being close to 0 , in general, the PSO was favorable for the drugs due to its ideal concentration together with the $\mathrm{pH}$, which was adjusted to give the zero charge point $\left(\mathrm{pH}_{\mathrm{ZCP}}\right)$.

\section{CONCLUSION}

Therefore, with the present work it was possible to identify the variability of the applicability of agro-industrial residues that can be used as biosorbents for the removal of drugs, in the removal of ibuprofen the biosorbent that had more prominence was the CM due to obtaining a monolayer adsorption by Freundlich with an n value of 1.9, in the case of paracetamol both IC and PS obtained 
good $\mathrm{Q}_{\max }$ of 200 and 113 respectively and $n$ values of 3.1 and 2.4 thus being an adsorption by multi and monolayer, finally for sodium diclofenac obtained the better $\mathrm{Q}_{\max }$ with the use of PCSP being 493.8 and an $n$ below 1, thus, a multilayer adsorption, in general the studies with Temkin mostly had a chemical adsorption due to having an energy greater than $20 \mathrm{~kJ} \mathrm{~mol}^{-1}$ except for the use of the RHA biosorbent and for the Sips parameters, the best $\mathrm{Q}_{\max }$ was using the COR biosorbent to remove sodium diclofenac. the kinetics showed that PSO presented the best results in the biosorption of drugs, due to its concentrations being ideal and in agreement with the $\mathrm{pH}$. Therefore, it is possible to identify a series of applications of alternative materials in the removal of organic pollutants, proving to be very sustainable and ecologically correct for these materials.

\section{ACKNOWLEDMENTS}

These authors want to appreciate the Brazilian National Council for Scientific and Technological Development (CNPq) and the Franciscan University (UFN) for the financial support to this work.

\section{REFERENCES}

ALVER, E.; METIN, A.Ü.; BROUERS, F. Methylene blue adsorption on magnetic alginate/rice husk bio-composite. International journal of biological macromolecules, v. 154, p. 104-113, 2020.

ATZENI, F.; MASALA, I.F.; PUTTINI, P.S. A review of chronic musculoskeletal pain: central and peripheral effects of diclofenac. Pain and therapy, v. 7, p. 163-177, 2018.

ATZENI, F.; MASALA, I.F.; BAGNASCO, M.; LANATA, L.; MANTELLI, F.; PUTTINI, P.S. Comparison of efficacy of ketoprofen and ibuprofen in treating pain in patients with rheumatoid arthritis: A systematic review and meta-analysis. Pain and Therapy, v. 10, p. 577-588, 2021.

BANU, H.; KARTHIKEYAN, P.; MEENAKSHI, S. Zr ${ }^{4+}$ ions embedded chitosan-soya bean husk activated bio-char composite beads for the recovery of nitrate and phosphate ions from aqueous solution. International Journal of Biological Macromolecules, v. 130, p. 573-583, 2019.

BEHERA, S.K.; OH, S.Y.; PARK, H.S. Sorptive removal of ibuprofen from water using selected soil minerals and activated carbon. International Journal of Environmental Science and Technology, v. 9, p. 85-94, 2012.

BELLO, S. O.; MOSHOOD, M.A.; EWETURMO, B.A.; AFOBALI, I.C. Ibuprofen removal using coconut husk activated biomass. Chemical Data Collections, v. 29, p. 100533-100542, 2020. 
BERNAL, V.; GIRALNDO, L.; MORENO-PIRAJÁN, J.C. Understanding the solid-liquid equilibria between Paracetamol and activated carbon: Thermodynamic approach of the interactions adsorbent-adsorbate using equilibrium, kinetic and calorimetry data. Journal of Hazardous Materials, v. 419, p. 126432-126445-126456, 2021.

BEYER, T.; DAY, G.M.; PRICE, S.L. The prediction, morphology, and mechanical properties of the polymorphs of paracetamol. Journal of the American Chemical Society, v. 123, p. 5086-5094, 2001.

BOTELLO-GONZÁLEZ, J.; DÁVILA-GUZMÁN, N.E.; SALAZAR-RÁBAGO, J.J. New generation of eco-friendly adsorbents for future water purification. Handbook of Nanomaterials and Nanocomposites for Energy and Environmental Applications, p. 2875-2897, 2021.

CABRITA, I.; RUIZ, B.; MESTRE, A.; FONSECA, I.M. Removal of an analgesic using activated carbons prepared from urban and industrial residues. Chemical Engineering Journal, v. 163, p. 249-255, 2010.

CAO, Y.; XIAO, W.; SHEN, G.; JI, G.; ZHANG, Y.; GAO, C.; HAN, L. Carbonization and ball milling on the enhancement of $\mathrm{Pb}$ (II) adsorption by wheat straw: Competitive effects of ion exchange and precipitation. Bioresource technology, v. 273, p. 70-76, 2019.

CHAKRABORTY, P.; BANERJEE, S.; KUMAR, S.; SADHUKHAN, S. Elucidation of ibuprofen uptake capability of raw and steam activated biochar of Aegle marmelos shell: Isotherm, kinetics, thermodynamics and cost estimation. Process Safety and Environmental Protection, v. 18, p. 10-23, 2018.

DA SILVA, A.L.; CASTAÑEDA-AYARZA, J.A. Macro-environment analysis of the corn ethanol fuel development in Brazil. Renewable and Sustainable Energy Reviews, v. 135, p. 110387-110401, 2021.

DA SILVA, W. L.; DOS SANTOS, J.H.Z. Ecotechnological strategies in the development of alternative photocatalysts. Current Opinion in Green and Sustainable Chemistry, v. 6, p. 63-68, 2017.

DUBRAY, C.; MAINCENT, P.; MILON, J.Y. From the pharmaceutical to the clinical: the case for effervescent paracetamol in pain management. A narrative review. Current Medical Research and Opinion, v. 37, p. 1039-1048, 2021. 
FARID, M.A.A.; HASSAN, M.A.; TAUFIQ-YAP, Y.H.; IBRAHIM, M.L.; HASAN, M.Y.; ALI, A.A.M.; OTHMAN, M.R. Kinetic and thermodynamic of heterogeneously $\mathrm{K}_{3} \mathrm{PO}_{4} / \mathrm{AC}$-catalysed transesterification via pseudo-first order mechanism and Eyring-Polanyi equation. Fuel, v. 232, p. 653-658, 2018.

FREUNDLICH, H. Adsorption in solution. Physical Chemistry. v. 57, p. 384-410, 1926.

GAMA, A.S.M.; SECOLI, S.R. Self-medication practices in riverside communities in the Brazilian Amazon Rainforest. Revista Brasileira de Enfermagem, v. 73, p. 1-9, 2020.

HUANG, D.; LI, B.; OU, J.; XUE, W.; LI, J.; LI, Z.; CHEN, S.; DENG, R.; GUO, X. Megamerger of biosorbents and catalytic technologies for the removal of heavy metals from wastewater: Preparation, final disposal, mechanism and influencing factors. Journal of Environmental Management, v. 261, p. 109879-109902, 2020.

HUBBE, M.A.; AZIZIAN, S., DOUVEN, S. Implications of Apparent Pseudo-Second-Order Adsorption Kinetics onto Cellulosic Materials: A Review. BioResources, v. 31, p. 7582-7626, 2019.

HUSSAIN, S.; KAMRAN, M.; KHAN, S.A.; SHAHEEN, K.; SHAH, Z.; SUO, H.; KHAN, Q.; SHAH, A.B.; REHMAN, W.U.; AL-GHAMDI, Y.O.; GHANI, U. Adsorption, kinetics and thermo-dynamics studies of methyl orange dye sequestration through chitosan composites films. International Journal of Biological Macromolecules, v. 168, p. 383-394, 2021.

KADAM, A.A.; SHARMA, B.; SARATALE, G.D.; SARATALE, R.G.; GHODAKE, G.S.; MISTRY, B.M.; SHINDE, S.K.; JEE, S.C.; SUNG, J.S. Super-magnetization of pectin from orange-peel biomass for sulfamethoxazole adsorption. Cellulose, v. 27, p. 3301-3318, 2020.

KARRI, R.R.; SAHU, J.N.; MEIKAP, B.C. Improving efficacy of Cr (VI) adsorption process on sustainable adsorbent derived from waste biomass (sugarcane bagasse) with help of ant colony optimization. Industrial Crops and Products, v. 143, p. 111927-111938, 2020.

KHADIR, A.; MOTAMEDI, M.; NEGARESTANI, M.; SILLANPÄÄ, M.; SASANI, M. Preparation of a nano bio-composite based on cellulosic biomass and conducting polymeric nanoparticles for ibuprofen removal: Kinetics, isotherms, and energy site distribution. International Journal of Biological Macromolecules, v. 162, p. 663-677, 2020. 
LANGMUIR, I. The adsorption of gases on plane surfaces of glass, mica and platinum. Journal of the American Chemical Society, v.40, n. 9, p. 1361-1403, 1918.

LU, Y.; FAN, L.; YANG, L. Y.; HUANG, F.; OUYANG, X. PEI-modified core-shell/bead-likeamino silica enhanced poly (vinyl alcohol)/chitosan for diclofenac sodium efficient adsorption. Carbohydrate Polymers, v. 229, p. 115459-115498, 2020.

MAIA, G.S.; DE ANDRADE, J.R.; DA SILVA, M.G.C.; VIEIRA, M.G.A Adsorption of diclofenac sodium onto commercial organoclay: Kinetic, equilibrium and thermodynamic study. Powder Technology, v. 345, p. 140-150, 2019.

MARTINEZ-BURGOS, W.J.; SYDNEY, E.B.; MEDEIROS, A.B.P.; MAGALHÃES, A.I.; DE CARVALHO, J.C.; KARP, S.G.; VANDENBERGHE, L.P.S.; LETTI, L.A.J.; SOCCOL, V.T.; PEREIRA, G.V.M.; RODRIGUES, C.; WOICIECHOWSKI, A.L.; SOCCOL, C.R. Agro-industrial wastewater in a circular economy: Characteristics, impacts and applications for bioenergy and biochemicals. Bioresource Technology, v. 341, p. 125795-125806, 2021.

MOJIRI, A.; ZHOU, J.; VAKILI, M.; LE, H.V. Removal performance and optimization of pharmaceutical micropollutants from synthetic domestic wastewater by hybrid treatment. Journal of Contaminant Hydrology, v. 235, p. 103736-103786, 2020.

OLUWATOYIN, A.O.; OLALEKAN, A.A. Adsorption of crude oil spill from aqueous solution using agro-wastes as adsorbents. Journal of Scientific Research and Reports, v. 27, p. 27-52, 2021.

PAROLINI, M. Toxicity of the Non-Steroidal Anti-Inflammatory Drugs (NSAIDs) acetylsalicylic acid, paracetamol, diclofenac, ibuprofen and naproxen towards freshwater invertebrates: A review. Science of the Total Environment, v. 740, p. 140043-140099, 2020.

PHASUPHAN, W.; PRAPHAIRAKSIT, N.; IMYIMR, A. Removal of ibuprofen, diclofenac, and naproxen from water using chitosan-modified waste tire crumb rubber. Journal of Molecular Liquids, v. 294, p. 111554-111562 2019.

PRIYA, A.K.; PACHAIAPPAN, R.; KUMAR, P.S.; JALIL, A.A.; VO, D.N.; RAJENDRAN, S. The war using microbes: A sustainable approach for wastewater management. Environmental Pollution, v. 275, p. 116598-116613, 2021. 
QUESADA, H.B.; BAPTISTA, A.T.A.; CUSIOLI, L.F.; SEIBERT, D.; BEZERRA, C.O., BERGAMASCO, R. Surface water pollution by pharmaceuticals and an alternative of removal by low-cost adsorbents: A review. Chemosphere, v. 222, p. 766-780, 2019.

RATHI, B.; KUMAR, P.S.; SHOW, P.L. A review on effective removal of emerging contaminants from aquatic systems: Current trends and scope for further research. Journal of Hazardous Materials, v. 409, p. 124413-124492, 2021.

RAVENNI, G.; CAFAGGI, G.; SÁROSSY, Z.; NIELSEN, K.T.R.; AHRENFELDT, J.; HENRIKSEN, U.B. Waste chars from wood gasification and wastewater sludge pyrolysis compared to commercial activated carbon for the removal of cationic and anionic dyes from aqueous solution. Bioresource Technology Reports, v. 10, p. 100421-100430, 2020.

RODRIGUES, D.L.C.; MACHADO, F.M.; OSÓRIO, A.G.; AZEVEDO, C.F.; LIMA, E.C.; DA SILVA, R.S.; LIMA, D.R.; GONÇALVES, F.M. Adsorption of amoxicillin onto high surface area-activated carbons based on olive biomass: kinetic and equilibrium studies. Environmental Science and Pollution Research, v. 27, p. 41394-41404, 2020.

SAAD, S.; OUAFI, S.; MEGUELLATI, H.; DJEMOUAI, N. Chemical diversity analysis and biological activities evaluation of different polyphenolic extracts of Marrubium deserti De Noé from Algeria. Journal of Ethnopharmacology, v. 281, p. 114494-114509, 2021.

SANTA, S.L.B.; CREMONEZI, G.O.G.; SOARES, T.C.; DEGGAU, A.B.; DE ANDRADE GUERRA, J.B.S.O. Healthy sustainable cities and the COVID-19 pandemic: A sustainable development goals perspective. Environmental Footprints and Eco-Design of Products and Processes, v. 2021, p. 141-167, 2021.

SHAHRAKI, Z.H.; SHARIFIFARD, H.; LASHANIZADEGAN, A. Grape stalks biomass as raw material for activated carbon production: synthesis, characterization and adsorption ability. Materials research express, v. 5, p. 055603-055615, 2018.

SHAKEEL, F.; HAQ, N.; AHMED, M.A.; GAMBHIR, D.; ALANAZI, F.K.; ALSARRA, I.A. Removal of diclofenac sodium from aqueous solution using water/Transcutol/ethylene glycol/Capryol-90 green nanoemulsions. Journal of Molecular Liquids, v. 199, p. 102-107, 2014. 
SIPS, R. On the Structure of a Catalyst Surface. The Journal of Chemical Physics, v. 16, p. 490-495, 1948.

SOTELO, J.L.; OVEJERO, G.; RODRIGUEZ, A.; ÁLVAREZ, S. Competitive adsorption studies of caffeine and diclofenac aqueous solutions by activated carbon. Chemical Engineering Journal, v. 240, p. 443-453, 2014.

STÜLTEN, D.; ZÜHLKE, S.; LAMSHÖFT, M.; SPITELLER, M. Occurrence of diclofenac and selected metabolites in sewage effluents. Science of the Total Environment, v. 405, p. 310-316, 2008.

SUN, Z.; QU, K.; CHENG, Y.; YOU, Y.; HUANG, Z.; UMAR, A.; IBRAHIM, Y.S.A.; ALGADI, H.; CASTAÑEDA, L.; COLORADO, H.A.; GUO, Z. Corncob-derived activated carbon for efficiently adsorption dye in sewage. ES Food \& Agroforestry, v. 4, p. 61-73, 2021.

TEMKIN, M.I. Adsorption equilibrium and kinetics of processes on non-homogeneous and on the interactions between the adsorbed molecules. The Journal of Physical Chemistry, v. 15, p. 296-332, 1941.

THAKUR, A.; SHARMA, N.; MANN, A. Removal of ofloxacin hydrochloride and paracetamol from aqueous solutions: Binary mixtures and competitive adsorption. Materials Today: Proceedings, v. 28, n. 3, p. 1514-1519, 2020.

THUE, P.S.; SOPHIA, A.C.; LIMA, E.C.; WAMBA, A.G.N.; ALENCAR, W.S.; REIS, G.S.; RODEMBUSCH, F.S.; DIAS, S.L.P. Synthesis and characterization of a novel organic-inorganic hybrid clay adsorbent for the removal of acid red 1 and acid green 25 from aqueous solutions. Journal of Cleaner Production, v. 171, p. 30-44, 2018.

TRAN, T.H.; LE, A.H.; PHAM, T.H.; NGUYEN, D.T.; CHANG, S.W.; CHUNG, W.J.; NGUYEN, D.D. Adsorption isotherms and kinetic modeling of methylene blue dye onto a carbonaceous hydrochar adsorbent derived from coffee husk waste. Science of the Total Environment, v. 725, p. 138325$138335,2020$.

ZHUANG, S.; CHEN R.; LIU, Y.; WANG, J. Magnetic COFs for the adsorptive removal of diclofenac and sulfamethazine from aqueous solution: Adsorption kinetics, isotherms study and DFT calculation. Journal of Hazardous Materials, v.385, p. 121596-121630, 2020. 
ŻÓŁTOWSKA-AKSAMITOWSKA, S.; BARTCZAK, P.; ZEMBRZUSKA, J.; JESIONOWSKI, T. Removal of hazardous non-steroidal anti-inflammatory drugs from aqueous solutions by biosorbent based on chitin and lignin. Science of The Total Environment, v. 612, p. 1223-1233, 2018. 